\title{
Pathogens Associated with Foliar Blight of Onion
}

\author{
Efath Shahnaz $^{1 *}$, V.K. Razdan ${ }^{2}$ and Saba Banday ${ }^{1}$ \\ ${ }^{1}$ Division of Plant Pathology, Sher-e-Kashmir University of Agricultural Sciences \& \\ Technology-Kashmir, Shalimar Campus, 190025 \\ ${ }^{2}$ Division of Plant Pathology, Sher-e-Kashmir University of Agricultural Sciences and \\ Technology of Jammu, Chatha, 180009, India
}

Corresponding author

\begin{tabular}{|c|c|}
\hline & A B S T R A C T \\
\hline Keywords & \multirow{4}{*}{$\begin{array}{l}\text { Onion is an important crop grown worldwide for its culinary and medicinal } \\
\text { properties. One of the major bottlenecks in its production is the foliar blight } \\
\text { disease. The disease is responsible for causing huge losses in its successful } \\
\text { production. Pathogens isolated from the onion foliar blight symptomatic leaves for } \\
\text { two successive cropping seasons were Alternaria alternata, A. porri, A. } \\
\text { tenuissima, Stemphylium vesicarium, Cladosporium allii-cepae and } \\
\text { Colletotrichum circinans. However, the relative occurrence of the pathogens } \\
\text { varied during the cropping season. }\end{array}$} \\
\hline $\begin{array}{l}\text { Onion, Foliar } \\
\text { blight, Fungal } \\
\text { pathogens }\end{array}$ & \\
\hline Article Info & \\
\hline $\begin{array}{l}\text { Accepted: } \\
\text { 15 June } 2018 \\
\text { Available Online: } \\
10 \text { July } 2018\end{array}$ & \\
\hline
\end{tabular}

\section{Introduction}

Among the various diseases of onion that are responsible for causing the widespread destruction of the crop, foliar blight is perhaps the most important and yet, least understood disease. The disease has been attributed to a number of pathogens but very few workers have realized that the disease is in fact caused by a number of pathogens in association. The pathogens considered in order of importance, include Perenospora destructor (Berk) Casp (downy mildew), Alternaria porri (Ellis) Cif.(purple blotch), Sclerotinia squamosa (Vienn. Bourg.) Dennis (leaf rot or blast),
Botrytis cinerea Rud. (leaf spot, collar rot), Cladosporium allii-cepae (Ranojevic) M. B. Ellis (leaf blotch), Puccinia allii (DC) Rud. (rust), Pleospora herbarium (Pers.ex Fr.) Rabert. (black stalk rot), Stemphylium vesicarium (Wallr.) Simmons (leaf blight), Glomerella cingulata (Stonem) Spauld. and Schrenk (seven curls disease) and Cercospora duddiae Welles (leaf spot) (Maude, 1990). The foliage fungal diseases of onion as reported by Mukerji and Bhasin (1986) include Alternaria porri, A. alternata, A. cepulicola, A. palandui, A. pallii, Colletotrichum lindemuthianum, Heterosporium allii cepae, Levuilla taurica, Macrophimina cladosporoides, Phyllosticta allii, Pithomyces maydicus, Puccinia porri 
and Stemphylium botroysum. Suheri and Price (2000) reported that both $A$. porri and $S$. vesicarium were potentially important pathogens of winter grown Allium crops and purple leaf blotch symptoms were considered to be a complex caused by both the pathogens. Stemphylium botryosum (Pleospora herbarum), S. vesicarium and Alternaria alternata were isolatedin 93.7, 12.5 and 50.0 per cent of the samples, respectively (Cova and Rodriguez, 2003).

Rarely only one pathogen is associated with the disease. Keeping in view this fact an experiment was undertaken at the University Research Farm, Faculty of Agriculture of the Sher-e-Kashmir University of Agricultural Sciences and Technology of Jammu to ascertain the true nature and etiology of the disease so that the appropriate management practices may be based on such information.

\section{Materials and Methods}

Disease samples with typical blight symptoms were collected in perforated polyethylene bags at regular intervals. Ten locations in seven villages of Jammu district belonging to three Tehsils, viz., Akhnoor, Bishnah and R. S. Pura; ten locations in two villages of Tehsil Reasi of district Udhampur; two locations in village Thandapani of Tehsil Sunderbani of district Rajouri; and eight locations in five villages of Tehsil Hiranagar of district Kathua, known for onion cultivation, were selected for recording the observations. Disease intensity was recorded at fifteen day intervals starting from the first week of February. During the survey all types of blight symptoms, including Alternaria blight, were considered and evaluated for their intensity.

The following scale was used for rating disease intensity (Sharma, 1986):

$0: \quad$ No disease symptoms
1: $\quad$ Few spots towards the tip, covering less than 10 per cent leaf area

2: Several dark purplish patches, covering less than 20 per cent leaf area

3: Several patches with paler outer zone, covering up to 40 per cent leaf area

4: $\quad$ Long streaks, covering 75 per cent leaf area or breaking of leaves from centre

5: $\quad$ Complete drying of leaves or breaking of leaves from base.

The per cent disease intensity (PDI) was calculated as given below (Wheeler, 1969):

$\mathrm{PDI}=$

Total sum of numerical ratings $\times 100$

Number of leaves observed $\times$ Maximum disease rating

Samples were collected from these locations after every fifteen days and brought to laboratory for disease assessment.

Disease lesions of $5-10 \mathrm{~mm}^{2}$, along with the healthy-looking tissue were cut from the leaves and stalks showing blight symptoms. The sterilized pieces were dried on sterile blotter paper, transferred aseptically to potato dextrose agar (PDA) poured petriplates and incubated at $25 \pm 2^{\circ} \mathrm{C}$ for 14 days, in an inverted position. The incubated plates were observed for the growth of fungal colonies from the second day onwards. Purification of the cultures was done by hyphal tip method and the cultures were maintained on PDA slants for further studies. The identification of the purified cultures was done with the help of standard texts and manuals (Simmons, 1967; Simmons, 1969; Subramanian, 1971 and Chowdhry et al., 2000). Frequency of the 
pathogens associated with the foliar blight of onion was calculated by assessing the recovery of each pathogen from the total number of isolations made.

Thirty five day old onion plants grown in 12" pots under glass house conditions were inoculated separately with the blight pathogens, isolated from the naturally infected disease samples. At the site of inoculation three pricks were given on the leaf tissue by a sterilized stainless steel needle and then $5 \mathrm{~mm}$ mycelial disc of ten day old pathogen culture was placed on it. Leaves kept as check were only pin pricked without placing mycelial disc on them. Observations on the symptom development were recorded after 24 hours of inoculation.

\section{Results and Discussion}

In Jammu district, the average disease intensity increased from $6.37 \pm 0.97$ per cent in the $7^{\text {th }}$ standard week (SW) to $20.91 \pm 4.80$ per cent in the $13^{\text {th }} \mathrm{SW}$ in the year 2005 , whereas, in the year 2006, the corresponding values were $3.57 \pm 0.18$ and $11.57 \pm 0.64$ per cent, respectively. The average disease intensity in the Udhampur district ranged from $4.56 \pm 0.36$ per cent in the $7^{\text {th }} \mathrm{SW}$ to $13.03 \pm 1.62$ per cent in the $13^{\text {th }} \mathrm{SW}$ in 2005 , and in the year 2006 , from $5.39 \pm 0.14$ per cent to $13.35 \pm 0.29$ per cent, respectively.

In the year 2005, in Rajouri district, the average disease intensity ranged from $13.31 \pm 0.14$ per cent in the $7^{\text {th }} \mathrm{SW}$ to $37.26 \pm 0.33$ per cent in the $13^{\text {th }} \mathrm{SW}$, whereas, in the year 2006, disease intensity of $2.32 \pm 0.35$ per cent was recorded in the $7^{\text {th }} \mathrm{SW}$ which increased to $15.98 \pm 6.68$ per cent in the $13^{\text {th }}$ SW. In Kathua district, the average disease intensity increased from $7.16 \pm 0.51$ per cent in the $7^{\text {th }} \mathrm{SW}$ to $25.43 \pm 2.33$ per cent in the $13^{\text {th }} \mathrm{SW}$, in the year 2005 , whereas, in the year 2006, the average disease intensity recorded was $4.35 \pm 0.10$ per cent and $16.99 \pm 3.03$ per cent, respectively.
Frequency of different foliar blight pathogens

Pathogens isolated from the onion foliar blight symptoms during two successive cropping seasons were Alternaria alternata, A. porri, A. tenuissima, Stemphylium vesicarium, Cladosporium allii-cepae and Colletotrichum circinans (Plate I and II). The relative occurrence of the pathogens varied during the cropping season (Table). A. alternata was isolated from 37.00 (January) to 55.25 (April) per cent of the diseased samples observed throughout the growing season.

The presence of $A$. porri was detected at the end of February (7.00 per cent) and was found to increase (31.25 per cent) with the crop growth during the month of March and reached its maximum frequency (75.60 per cent) towards the end of cropping season in April. The per cent incidence of $A$. tenuissima ranged from 1-10 per cent throughout the crop period. Stemphylium vesicarium was also invariably found associated with typical blighted onion leaves throughout the growing period ( 82.75 per cent in January to 77.40 per cent in February), though its relative occurrence declined slightly in March (49.15 per cent) and April (37.75 per cent). Cladosporium allii-cepae was isolated in only 1 per cent of the diseased leaves in February and 3.75 per cent in March, whereas, Colletotrichum circinans was isolated from February (2.25 per cent) to April (4.25 per cent).

\section{Symptomatology}

It was observed that the infection by each of the six foliar blight pathogens viz., Alternaria alternata, A. porri, A. tenuissima, Stemphylium vesicarium, Colletotrichum alliicepa and Cladosporium allii-cepae resulted in distinct symptom expressions on the host (onion). 
Table.1 Per cent disease intensity of onion foliar blight at various locations in Jammu division during the first year

\begin{tabular}{|c|c|c|c|c|c|}
\hline \multirow[t]{2}{*}{ District/Tehsil } & \multirow[t]{2}{*}{ Location } & \multicolumn{4}{|c|}{ Standard week } \\
\hline & & 7 & 9 & 11 & 13 \\
\hline \multirow{3}{*}{$\begin{array}{l}\text { Jammu } \\
\text { Akhnoor }\end{array}$} & & & & & \\
\hline & Sidharuan & 06.53 & 09.71 & 10.10 & 11.91 \\
\hline & Garkhal & 05.63 & 08.15 & 17.55 & 23.68 \\
\hline \multirow[t]{4}{*}{ Bishnah } & Kotli I & 09.71 & 10.29 & 18.95 & 30.16 \\
\hline & Kotli II & 03.30 & 05.63 & 10.92 & 23.57 \\
\hline & Kotli III & 02.93 & 08.66 & 08.89 & 25.49 \\
\hline & Ismailpur & 05.02 & 06.63 & 12.87 & 22.41 \\
\hline \multirow{5}{*}{ R. S. Pura } & Prithvipur & 02.19 & 03.43 & 04.65 & 09.32 \\
\hline & Tale & 08.55 & 12.48 & 18.45 & 22.32 \\
\hline & Chakroi I & 11.48 & 17.16 & 18.89 & 21.69 \\
\hline & Chakroi II & 08.44 & 16.23 & 19.88 & 22.53 \\
\hline & Mean \pm S.E.(m) & $6.37 \pm 0.97$ & $9.83 \pm 1.91$ & $14.12 \pm 2.83$ & $20.91 \pm 4.80$ \\
\hline \multirow[t]{11}{*}{$\begin{array}{l}\text { Udhampur } \\
\text { Reasi }\end{array}$} & Aghar Balliyan I & 03.30 & 04.95 & 06.82 & 08.10 \\
\hline & Aghar Balliyan II & 01.19 & 03.50 & 05.42 & 06.18 \\
\hline & Aghar Balliyan III & 02.63 & 04.82 & 07.84 & 10.00 \\
\hline & Aghar Balliyan IV & 05.19 & 06.75 & 10.00 & 13.00 \\
\hline & Aghar BalliyanV & 04.32 & 06.16 & 12.14 & 13.25 \\
\hline & Aghar Balliyan VI & 05.51 & 07.26 & 10.81 & 13.96 \\
\hline & Aghar Balliyan VII & 04.10 & 05.34 & 13.12 & 15.00 \\
\hline & Gran Morh I & 05.21 & 06.54 & 11.66 & 14.10 \\
\hline & Gran Morh II & 06.25 & 10.40 & 15.32 & 17.17 \\
\hline & Gran Morh III & 07.86 & 09.94 & 14.91 & 19.56 \\
\hline & Mean \pm S.E. (m) & $4.56 \pm 0.36$ & $6.57 \pm 0.48$ & $10.80 \pm 1.10$ & $13.03 \pm 1.62$ \\
\hline \multirow[t]{3}{*}{$\begin{array}{l}\text { Rajouri } \\
\text { Sunderbani }\end{array}$} & Thandapani I & 13.68 & 22.39 & 27.25 & 35.97 \\
\hline & Thandapani II & 12.93 & 22.53 & 29.11 & 38.55 \\
\hline & Mean \pm S.E. (m) & $13.31 \pm 0.14$ & $22.46 \pm 0.05$ & $28.18 \pm 0.17$ & $37.26 \pm 0.33$ \\
\hline \multirow[t]{9}{*}{$\begin{array}{l}\text { Kathua } \\
\text { Hiranagar }\end{array}$} & Gadyal I & 09.96 & 11.32 & 15.63 & 19.18 \\
\hline & Gadyal II & 06.29 & 13.14 & 23.74 & 31.68 \\
\hline & Gadyal III & 07.25 & 13.40 & 22.34 & 27.66 \\
\hline & Gadyal IV & 06.35 & 07.93 & 16.00 & 22.69 \\
\hline & Khangal & 04.51 & 11.82 & 21.07 & 23.38 \\
\hline & Daichak & 09.61 & 18.80 & 21.67 & 28.39 \\
\hline & Nathal Chak & 08.57 & 13.68 & 18.34 & 28.87 \\
\hline & Pargwal & 05.06 & 09.07 & 18.47 & 21.58 \\
\hline & Mean \pm S.E. (m) & $7.16 \pm 0.51$ & $12.39 \pm 1.37$ & $19.66 \pm 1.12$ & $25.43 \pm 2.33$ \\
\hline
\end{tabular}


Table.2 Per cent disease intensity of onion foliar blight at various locations in Jammu division during the second year

\begin{tabular}{|c|c|c|c|c|c|}
\hline \multirow[t]{2}{*}{ District/Tehsil } & \multirow[t]{2}{*}{ Location } & \multicolumn{4}{|c|}{ Standard week } \\
\hline & & 7 & 9 & 11 & 13 \\
\hline \multirow{3}{*}{$\begin{array}{l}\text { Jammu } \\
\text { Akhnoor }\end{array}$} & & & & & \\
\hline & Sidharuan & 02.12 & 04.00 & 06.93 & 08.79 \\
\hline & Garkhal & 03.42 & 05.02 & 06.63 & 08.36 \\
\hline \multirow[t]{2}{*}{ Bishnah } & Kotli I & 04.93 & 08.95 & 12.48 & 15.00 \\
\hline & Kotli II & 04.72 & 08.79 & 10.45 & 13.68 \\
\hline \multirow{7}{*}{ R. S. Pura } & Kotli III & 05.83 & 09.32 & 10.10 & 12.41 \\
\hline & Ismailpur & 01.77 & 03.42 & 05.86 & 07.63 \\
\hline & Prithvipur & 02.91 & 04.31 & 07.77 & 10.93 \\
\hline & Tale & 03.41 & 06.63 & 09.71 & 12.31 \\
\hline & Chakroi I & 04.33 & 07.55 & 08.15 & 13.05 \\
\hline & Chakroi II & 02.22 & 04.65 & 08.86 & 13.58 \\
\hline & Mean \pm S.E.(m) & $3.57 \pm 0.18$ & $6.26 \pm 0.51$ & $8.69 \pm 0.41$ & $11.57 \pm 0.64$ \\
\hline \multirow[t]{11}{*}{$\begin{array}{l}\text { Udhampur } \\
\text { Reasi }\end{array}$} & Aghar Balliyan I & 04.22 & 07.36 & 09.09 & 11.97 \\
\hline & Aghar Balliyan II & 05.42 & 11.32 & 12.93 & 14.10 \\
\hline & Aghar Balliyan III & 04.33 & 09.03 & 11.58 & 13.00 \\
\hline & Aghar Balliyan IV & 06.63 & 10.52 & 11.82 & 13.40 \\
\hline & Aghar BalliyanV & 05.97 & 09.82 & 12.30 & 15.00 \\
\hline & Aghar Balliyan VI & 03.16 & 06.69 & 08.48 & 09.53 \\
\hline & Aghar Balliyan VII & 06.78 & 11.97 & 13.26 & 15.02 \\
\hline & Gran Morh I & 05.29 & 10.00 & 11.32 & 14.93 \\
\hline & Gran Morh II & 05.45 & 10.45 & 12.93 & 14.08 \\
\hline & Gran Morh III & 06.63 & 08.15 & 10.92 & 12.48 \\
\hline & Mean \pm S.E. $(\mathrm{m})$ & $5.39 \pm 0.14$ & $9.53 \pm 0.29$ & $11.46 \pm 0.26$ & $13.35 \pm 0.29$ \\
\hline \multirow[t]{3}{*}{$\begin{array}{l}\text { Rajouri } \\
\text { Sunderbani }\end{array}$} & Thandapani I & 01.72 & 03.43 & 05.02 & 18.56 \\
\hline & Thandapani II & 02.91 & 04.61 & 06.83 & 13.39 \\
\hline & Mean \pm S.E. $(\mathrm{m})$ & $2.32 \pm 0.35$ & $4.02 \pm 0.35$ & $5.93 \pm 0.82$ & $15.98 \pm 6.68$ \\
\hline \multirow[t]{9}{*}{$\begin{array}{l}\text { Kathua } \\
\text { Hiranagar }\end{array}$} & Gadyal I & 02.93 & 05.63 & 08.15 & 10.08 \\
\hline & Gadyal II & 04.72 & 07.39 & 12.61 & 15.62 \\
\hline & Gadyal III & 05.45 & 14.88 & 17.16 & 23.57 \\
\hline & Gadyal IV & 03.98 & 05.02 & 12.48 & 20.69 \\
\hline & Khangal & 05.52 & 10.92 & 15.62 & 18.89 \\
\hline & Daichak & 04.65 & 06.38 & 13.68 & 14.88 \\
\hline & Nathal Chak & 03.43 & 06.52 & 07.74 & 10.92 \\
\hline & Pargwal & 04.10 & 05.02 & 12.87 & 21.30 \\
\hline & Mean \pm S.E. $(\mathrm{m})$ & $4.35 \pm 0.10$ & $7.72 \pm 1.49$ & $12.54 \pm 1.33$ & $16.99 \pm 3.03$ \\
\hline
\end{tabular}




\section{PLATE I}

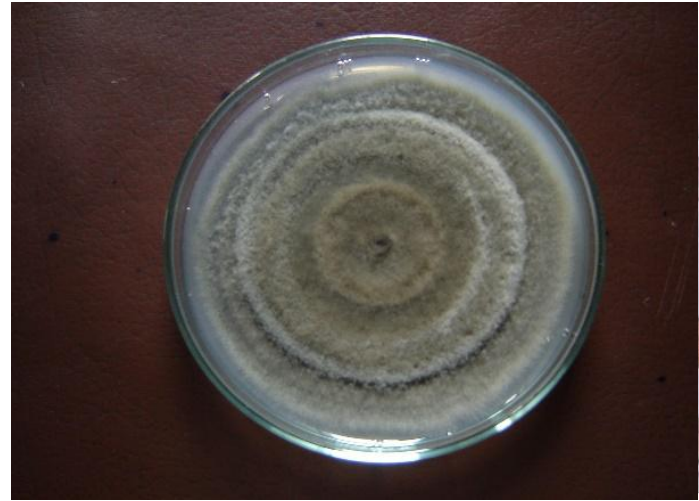

(a)

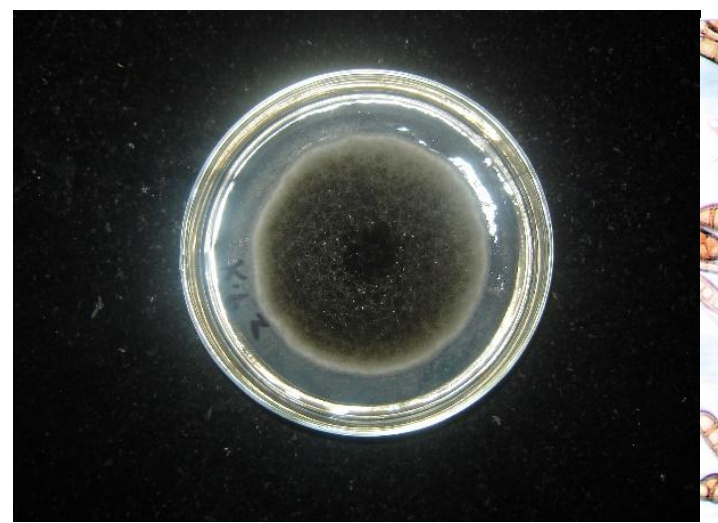

(b)

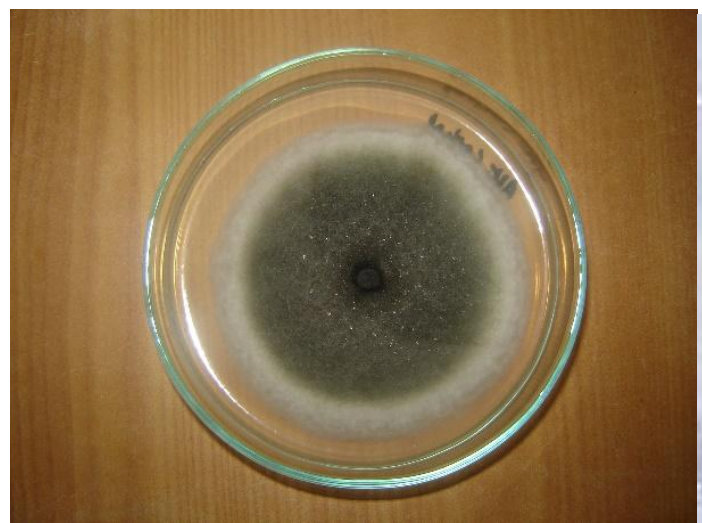

(c)

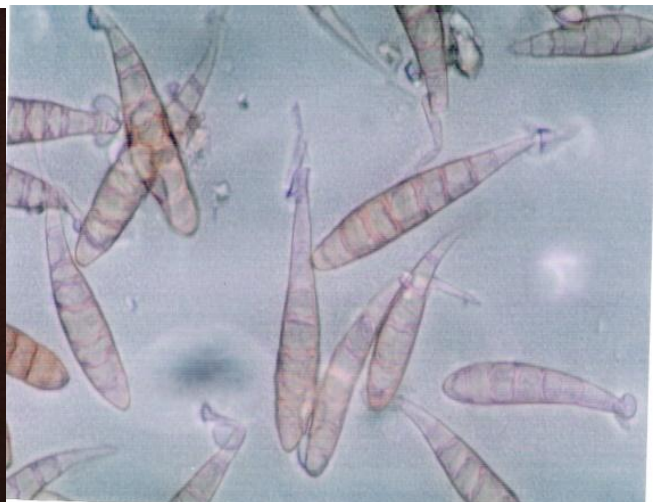

(d)

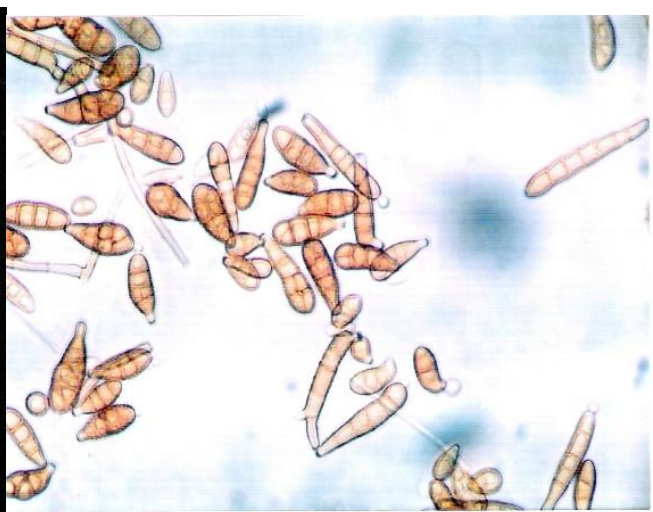

(e)

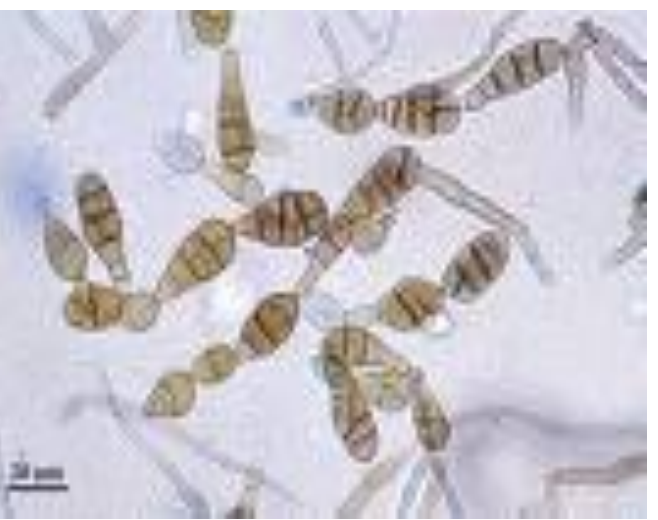

(f)

Cultural characteristics of (a) Alternaria porri, (b) Alternaria tenuissima and (c) Alternaria alternata; Conidia of (d)Alternaria porri, (e) Alternaria tenuissima and (f) Alternaria alternata 


\section{PLATE II}

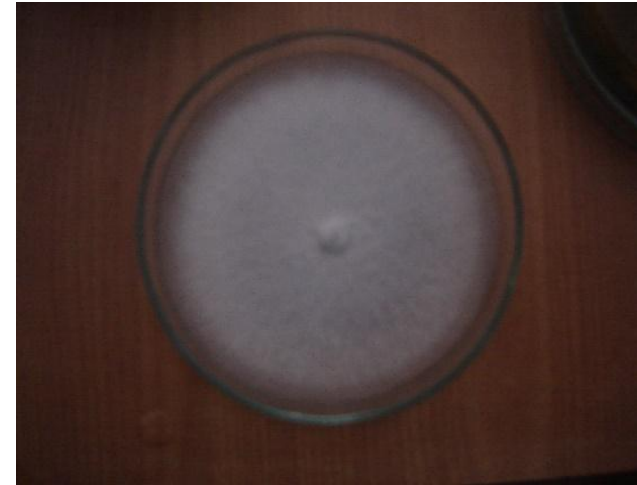

(g)

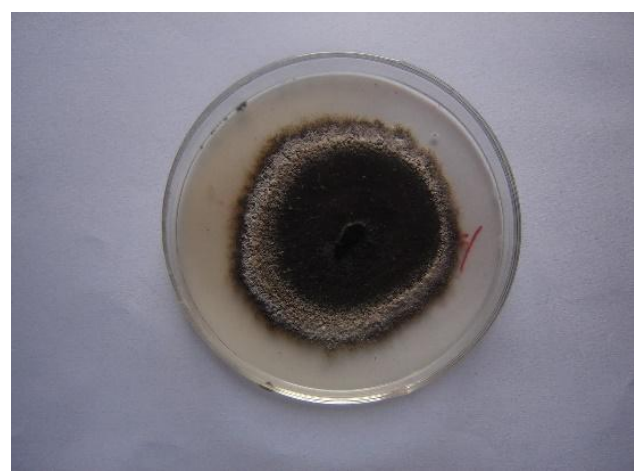

(h)

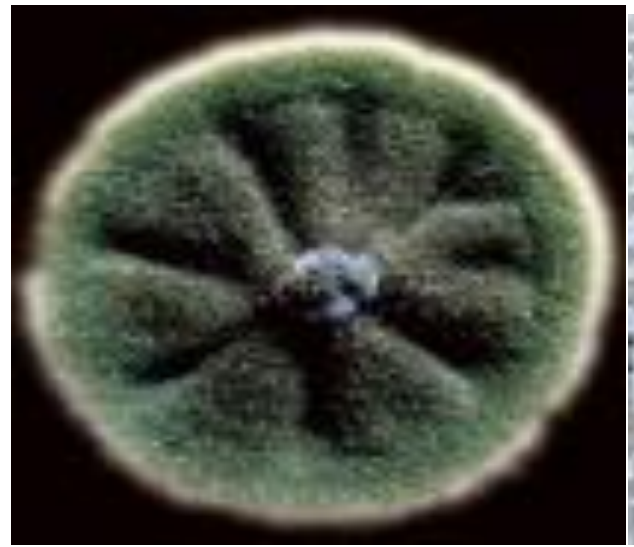

(i)

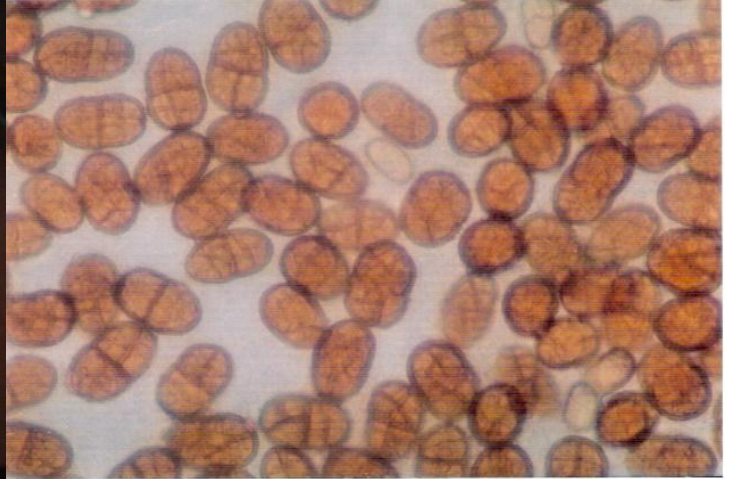

(j)

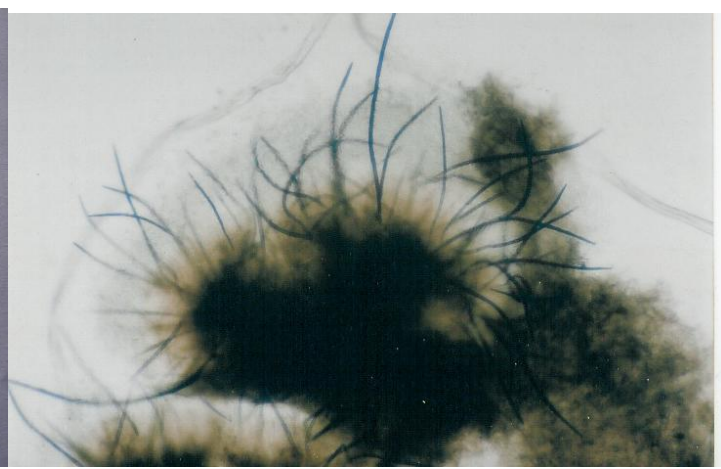

(k)

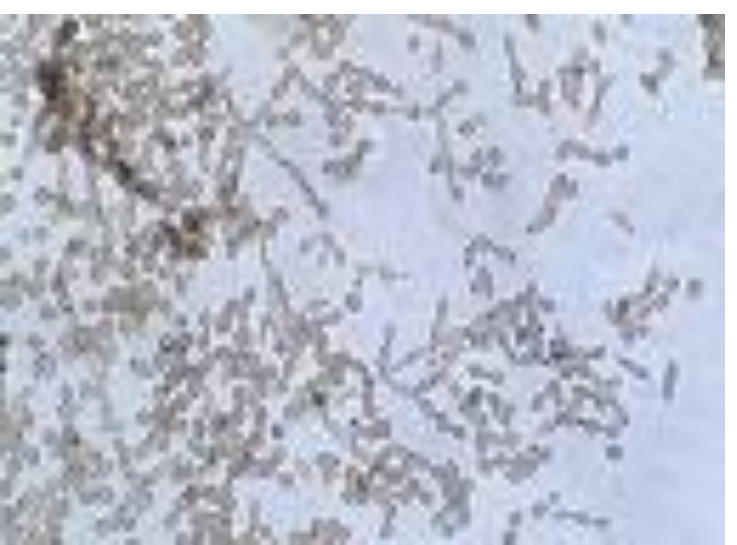

(l)

Cultural characteristics of (g) Stemphylium vesicarium, (h) Colletotrichum allii-cepa and (i) Cladosporium allii-cepae; Conidia of (j) Stemphylium vesicarium, (k) Colletotrichum allii-cepa and (1) Cladosporium allii-cepae 
Table.3 Frequency of different foliar blight pathogens associated with the onion crop for two successive cropping seasons

\begin{tabular}{|c|c|c|c|c|c|c|c|c|c|c|c|c|}
\hline \multirow[t]{2}{*}{ Pathogen } & \multicolumn{3}{|c|}{ January } & \multicolumn{3}{|c|}{ February } & \multicolumn{3}{|c|}{ March } & \multicolumn{3}{|c|}{ April } \\
\hline & $\begin{array}{c}1^{\text {st }} \\
\text { year }\end{array}$ & $\begin{array}{c}2^{\text {nd }} \\
\text { Year }\end{array}$ & Average & $\begin{array}{c}1^{\text {st }} \\
\text { year }\end{array}$ & $\begin{array}{c}2^{\text {nd }} \\
\text { Year }\end{array}$ & Average & $\begin{array}{c}1^{\text {st }} \\
\text { year }\end{array}$ & $\begin{array}{c}2^{\text {nd }} \\
\text { Year }\end{array}$ & Average & $\begin{array}{c}1^{\text {st }} \\
\text { year }\end{array}$ & $\begin{array}{c}2^{\text {nd }} \\
\text { Year }\end{array}$ & Average \\
\hline Alternaria alternata & 39.00 & 35.00 & 37.00 & 42.50 & 38.00 & 40.25 & 51.50 & 45.00 & 48.25 & 60.00 & 50.50 & 55.25 \\
\hline Alternaria porri & 00.00 & 00.00 & 00.00 & 09.00 & 05.00 & 07.00 & 33.50 & 29.00 & 31.25 & 80.70 & $\mathbf{7 0 . 5 0}$ & 75.60 \\
\hline Alternaria tenuissima & 02.50 & 00.50 & 01.50 & 04.80 & 02.00 & 03.40 & 07.00 & $\mathbf{0 5 . 5 0}$ & 06.25 & 11.30 & 08.30 & 09.80 \\
\hline Stemphylium vesicarium & 85.50 & 80.00 & 82.75 & 79.30 & $\mathbf{7 5 . 5 0}$ & 77.40 & 55.00 & 43.30 & 49.15 & 40.50 & 35.00 & 37.75 \\
\hline Cladosporium allii-cepae & 00.00 & 00.00 & 00.00 & 02.00 & 00.00 & 01.00 & 05.00 & 02.50 & 03.75 & 00.00 & 00.00 & 00.00 \\
\hline Colletotrichum circinans & 00.00 & 00.00 & 00.00 & 02.50 & 02.00 & 02.25 & 04.30 & 03.50 & 03.90 & 04.50 & 04.00 & 04.25 \\
\hline
\end{tabular}

Mean of 500 readings

On the leaves inoculated with A. porri, small, sunken, whitish flecks with purple coloured centres developed which later on coalesced to form large dead patches covering several square centimeters of the leaf. The purplish area of the spot was separated from the healthy green tissues by a narrow, light coloured zone. Within a period of 15-21 days, alternating light and dark zones became clearly differentiated over the whole purple surface of the leaf. Both A. alternata and $A$. tenuissima also formed similar purple patches as in case of $A$. porri. The patches enlarged and resulted in blight and wither-tip. The inoculations made with $S$. vesicarium manifested into small, white, spindle-like lesions which turned to light yellow in colour and later changed to brown or purple. Within few days, the entire leaf had a blighted appearance. The spots caused by the inoculations with $C$. allii-cepae were pale brown in colour, which enlarged into lens shaped lesions. The leaves appeared blighted under warm and moist conditions. The inoculations with $C$. circinans resulted in the development of small, black coloured lesions which were surrounded by a pale outer zone. Slightly raised acervuli of the fungus became clearly visible on the inoculated leaves at the later stage.

Under the field conditions it was observed that the conidia belonging to Alternaria porri and Stemphylium vesicarium were associated with the purple and black lesions (Plate III, c and d), whereas, A. alternata, A. tenuissima and $S$. vesicarium were isolated mostly from blighted portions. Cladosporium allii-cepae was commonly isolated from the blighted leaves showing velvety growth of fungus. Colletotrichum circinans was isolated from relatively few lesions during the growth period of the onion crop. However, the acervuli of $C$. circinans were clearly distinguishable on the dried seed stalk debris owing to the formation of black raised lesions (Plate III, f).

Pathogens found associated with the foliar blight were Alternaria alternata, A. porri, A. tenuissima, Stemphylium vesicarium, Cladosporium allii-cepae and Colletotrichum circinans. However, the relative occurrence of the pathogens varied during the cropping season. A. alternata was isolated from 37.0055.25 per cent of the diseased leaf samples observed throughout the growing season. Cova and Rodriguez (2001) have also found A. alternata to be responsible for the foliar blight of onion. Linares and Gracia (1985) reported that plants kept in an inoculation chamber and inoculated with A. alternata developed symptoms very similar to those of $A$. porri. The presence of $A$. porri was 
detected at the end of February (7.00 per cent) and was found to increase with the crop growth and reached its maximum frequency (75.60 per cent) towards the end of the cropping season in April. Similar results were reported by Ariosa and Herrara (1984) who noted that the first symptoms of the disease appeared 50 days after sowing and disease intensity was highest at 110 days after sowing. Chawda and Rajasab (1994) also reported that purple blotch symptoms appeared in the field five days after the first rain after transplantation. Warm weather with occasional rains has been described as ideal conditions for epiphytotic development of the disease caused by A. porri (Nolla, 1927). Similar weather conditions prevailed from the second fortnight of February onwards in both the successive cropping seasons resulting in conducive environment for the disease development. Onion leaves have been reported to become more susceptible to $A$. porri as they age and bulbs approach maturity (Miller, 1983). Lakra (1999) also reported that purple blotch/spot started appearing in mid-February and became supernumery by end of March.

A. tenuissima was isolated from 1-10 per cent of the blighted leaves throughout the growing period. It has been found that A. tenuissima could cause considerable damage, especially by top killing of the foliage (Skiles, 1953). Our observation of more than one species being responsible for onion foliar blight is in conformity to the findings of Skiles (1953) who had proposed the name "Alternaria blotch" to describe the disease complex of onion caused by three species of Alternaria, viz., A. porri, A. tenuis and A. tenuissima.

Stemphylium vesicarium was invariably found associated with typically blighted onion leaves throughout the growing period $(82.75$ per cent in January to 77.40 per cent in February), though its relative occurrence declined slightly in March (49.15 per cent) and April (37.75 per cent). The results of the present study are in conformity with Jakhar et al. (1996) who reported that the disease caused by Stemphylium first increased gradually, and then decreased late in the season. The results of the present study revealed that the symptoms of $A$. porri and $S$. vesicarium were indistinguishable in the field, which is in conformity with the results of Suheri and Price (2000) who reported that typical purple blotch lesions in the field were often colonized by both the pathogens. Aveling et al., (1993) showed that $S$. vesicarium, in conjunction with $A$. porri, was a destructive foliar and seed stalk pathogen of onion under warm, moist conditions.

Cladosporium allii-cepae was isolated in only 1 per cent of the diseased leaves in February and 3.75 per cent in March, whereas, Colletotrichum circinans was isolated from February (2.25 per cent) to April (4.25 per cent). Ryan et al. (1981) also reported severe blighting of onion crop due to $C$. allii-cepae, which usually coincided with the onset of senescence in the foliage. Hall and Kavanagh (1985) reported that $C$. allii-cepae forms an olive green velvety growth of sporulating mycelium on the surface of lesions and under conditions conducive to disease development the crop appeared blighted. Young, bleached lesions, typical of $A$. porri infection in dry conditions, might be confused with those of C. allii-cepae (Ryan, 1978). Gupta et al. (1994) have identified Stemphylium blight ( $S$. vesicarium) and purple blotch (A. porri) as diseases of national importance, whereas, Colletotrichum blight was found to be localized in Maharashtra.

\section{References}

Ariosa, T. M. and Herrera, I. L. (1984). Evaluation of damage caused by purple spot (Alternaria porri) in two 
onion varieties (Allium cepa) and in leek (Allium porrum). Centro Agricola11: 15-20

Aveling, T. A. S., Snyman, H. G. and Naude, S. P. (1993). Evaluation of seed treatments for reducing Alternaria porri and Stemphylium vesicarium on onion seed. Plant Disease 77: 10091011

Chawda, H. T. and Rajasab, A. H. (1994). Aerobiology of Alternaria porri and its relation to purple blotch disease in onion. Indian Journal of Mycology and Plant Pathology24: 41-45

Chowdhry, P. N., Lal, S. P., Mathur, N. and Singh, D. V. (2000). Manual on Identification of Plant Pathogenic and Biocontrol Fungi of Agricultural Importance. Indian Agricultural Research Institute 149pp.

Cova, J. and Rodriguez, D. (2001). Effect of temperature and relative humidity on leaf blight in onion (Allium cepa L.). Proceedings of the Interamerican Society for Tropical Horticulture 45: 95-97

Cova, J. and Rodriguez, D. 2003. Fungi associated with leaf blight of onion (Allium cepa L.) in Lara State, Venezuela. Bioagro 15: 157-163.

Gupta, R. P., Srivastava, K. J., Pandey, U. B. and Midmore, D. J. (1994). Diseases and insect pests of onion in India. Acta Horticulturae 358: 265-269

Hall, K. and Kavanagh, J. A.. (1985). Light and scanning electron microscope studies of leaf blotch of onion caused by Cladosporium allii-cepae. Plant Pathology35: 1-4

Jakhar, S. S., Duhan, J. C. and Suhag, L. S. (1996). Studies on the epidemiology and survival of Stemphylium vesicarium (Wallr.) Simmons in debris and seeds of onion. Seed Research24: $135-140$

Lakra, B. S. (1999). Develpoment of purple blotch incited by Alternaria porri and its losses in seed crop of onion (Allium cepa). Indian Journal of Agricultural Science69: 144-146

Linares, C. J. J. and Gracia, C. I. (1985). Alternaria alternata on onion (Allium cepa). Ciencias de la Agricultura 23: 122-123

Maude, R. B. 1990. Leaf diseases of onions. In: Onions and Allied Crops. Vol. II. Rabinowitch, H. D. and Brewster, J. L. (eds.) CRC Press, Inc Boca Raton, Florida, 173-189.

Miller, M. E. (1983). Relationships between leaf age and susceptibility to Alternaria porri. Plant Disease67: 284-286

Mukerji, K. G. and Bhasin, J. 1986. In: Plant Diseases of India-A Source Book. Tata McGraw Hill Publishing Company Ltd., New Delhi.

Nolla, J. A. B. (1927). A new Alternaria disease of onion (Allium cepa L.) Phytopathology 17: 115-132

Ryan, E. W. (1978). Leaf spot of onions caused by Cladosporium allii-cepae. Plant Pathology27: 200

Sharma, S. R. 1986. Effect of fungicidal sprays on purple blotch and bulb yield of onion. Indian Phytopathology 39:78-82.

Simmons, E. G. (1967). Typification of Alternaria, Stemphylium and Ulocladium. Mycologia59: 67-92

Simmons, E. G. (1969). Perfect states of Stemphylium. Mycologia61: 1-26

Skiles, R. L. (1953). Purple and brown blotch of onions. Phytopathology 43: 409412

Subramanian, G. V. (1971). Hyphomycetes: An account of Indian species. Indian Council of Agricultural Research, New Delhi, 613 pp

Suheri, H. and Price, T. V. (2000). Infection of onion leaves by Alternaria porri and Stemphylium vesicarium and 
disease development in controlled environments. Plant Pathology49: 375-382

Suheri, H. and Price, T. V. 2000. Infection of onion leaves by Alternaria porri and Stemphylium vesicarium and disease development in controlled environments. Plant Pathology 49: 375-382.

Wheeler, B. E. J. 1969. An Introduction to Plant Disease. John Wiley, London, $301 \mathrm{pp}$.

\section{How to cite this article:}

Efath Shahnaz, V.K. Razdan and Saba Banday. 2018. Pathogens Associated with Foliar Blight of Onion. Int.J.Curr.Microbiol.App.Sci. 7(07): 2048-2058.

doi: https://doi.org/10.20546/ijcmas.2018.707.242 